\title{
養豚一貫経営の肉豚事故率別における肥育成績 および枝肉生産費の比較
}

\author{
今田哲雄・齋藤常幸・川村信雄* \\ 山形県立養豚試験場, 酒田市, 998-0112 \\ *山形県畜産会, 山形市, 990-0825
}

(2000 年 9 月 11 日受付)

\begin{abstract}
緒 言
本県の養豚一貫経営の肥育技術の特徴として, 肉豚事故率の高いことが問題化している。中央畜 産会調査による全国先進事例の肉豚事故率を対肉 豚出荷頭数として算出し, 求めた肉豚事故率は平 成 7 年が $3.1 \%$, 平成 8 年は $4.3 \%$, 平成 9 年は $4.5 \%$ である ${ }^{1)}$ 。また, 本県の先進事例の養豚一貫 経営 5 例における肉豚事故率は平成 7 年が $7.7 \%^{2)}$, 平成 8 年が $6.5 \%{ }^{3)}$, 平成 9 年は $8.7 \% \%^{4)}$ と, 全国水準に比べ高く推移している。

中央畜産会で実施している畜産コンサルタント では, 肉豚の事故に係わる飼料給与量および飼料 費は調査成績から除外することなく集計すること から, 肉豚事故率が高くなると飼料要求率は劣 り, 増体 $1 \mathrm{~kg}$ 当たり飼料費が高くなり, その結果 枝肉生産費む高くなると予測される。従って, 養 豚一貫経営において枝肉生産費の低減を図るには 肥育部門の技術改善として飼料要求率低減が求め られ，そのためには肉豚事故率を低減することが 望まれる。

そこで, 養豚一貫経営における肥育技術の向上 を目的として, 養豚一貫経営を離乳後から出荷時
\end{abstract}

までの育成および肥育期における肉豚事故率別に 区分して, 肥育成績および経済性について比較検 討した。

\section{材料および方法}

\section{（1） 供試材料}

本調査に供試した材料は平成 6 年度から平成 9 年度に山形県畜産会の畜産コンサルタントを受診 した養豚一貫経営 118 戸の経営実績である。本調 査で対象とした養豚一貫経営における肉豚は自家 で生産し, その肉豚の事故率の全平均值が $10.2 \%$ であったことから，10\%を基準として区分した。 そして, 養豚一貫経営における肥育成績および経 済性に対する肉豚事故率の影響をより把握するこ とと, 本県における肉豚事故率低減に関する目標 を求めるために, 平均より低い区は $2.5 \%$ 毎減ら した 3 区（1区，2区および 3 区）に設定し，平均 より高い区は 5\% 毎増やした 3 区 (4区，5区およ び 6 区）とし，計 6 区に設定した。

本調査における肉豚事故の対象期間は離乳後 （体重約 $8 \mathrm{~kg}$ ) から出荷時（体重約 $108 \mathrm{~kg}$ ) までで あり, 肉豚事故率の算出は年間の肉豚事故頭数を 肉豚出荷頭数で除して求めた。つまり, 式で表す

Comparision of the Characteristics of Growing-Fattening Pig and Dressed Carcass Production Cost in relation to the Mortality by Accident in Hogs on Farrow to Finishing Type Swine Farms

T. Konta, T. Saitoh and N. Kawamura*

Yamagata Prefectural Experiment Station of Swine Husbundry, Sakata-shi, 998-0112

${ }^{*}$ Yamagata Livestock Association, Yamagata-shi, 990-0825

key word : Mortality by accident in hogs, Growing-fattening pig, Production cost, Swine farms 
表 1. 調査対象とした養豚一貫経営の経営概況

\begin{tabular}{|c|c|c|c|c|}
\hline \multirow{3}{*}{ 区 } & \multirow{3}{*}{ 肉豚事故率 } & \multirow{3}{*}{$\begin{array}{l}\text { 調查対象 } \\
\text { 農家 }\end{array}$} & \multicolumn{2}{|c|}{ 常時飼養頭数 } \\
\hline & & & 繁殖雌豚 & 肉豚 \\
\hline & & & 平均（最小〜最大） & 平均（最小～最大） \\
\hline & $(\%)$ & （戸） & (頭） & (頭) \\
\hline 1 & $\sim 5.0$ & 27 & $52.3(17.8 \sim 134.1)$ & $493.7(174.4 \sim 1,337.3)$ \\
\hline 2 & $5.0 \sim 7.5$ & 25 & $60.2(27.9 \sim 129.8)$ & $595.4(222.8 \sim 1,351.9)$ \\
\hline 3 & $7.5 \sim 10.0$ & 21 & $78.5(19.9 \sim 155.2)$ & $760.9(177.8 \sim 1,468.3)$ \\
\hline 4 & $10.0 \sim 15.0$ & 18 & $64.1(19.5 \sim 129.8)$ & $644.8(168.9 \sim 1,432.0)$ \\
\hline 5 & $15.0 \sim 20.0$ & 16 & $64.6(18.9 \sim 129.5)$ & $630.9(181.2 \sim 1,420.8)$ \\
\hline 6 & $20.0 \sim$ & 11 & $57.7(48.9 \sim 71.2)$ & $529.2(353.5 \sim 609.3)$ \\
\hline \multicolumn{2}{|c|}{ 計または平均 } & 118 & $62.6(17.8 \sim 155.2)$ & $607.8(168.9 \sim 1,468.3)$ \\
\hline
\end{tabular}

と次のようになる。

肉豚事故率 $(\%)=$ 肉豚事故頭数 (年間) /肉豚 出荷頭数 (年間) $\times 100$

表 1 に調查対象とした養豚一貫経営における繁 殖雌豚および肉豚の飼養状況を示した。養豚一貫 経営 118 戸の繁殖雌豚抢よび肉豚の常時飼養頭数 の平均はそれぞれ 62.6 頭および 607.8 頭であっ た。

調査項目は次のとおりである。肥育技術は, 素 豚体重, 出荷体重, 1 日平均増体重, 飼料要求率, 肉豚 1 頭当たり平均飼料給与量（以下，飼料給与
量), 子豚育成期飼料給与量, 子豚期飼料給与量, 肉豚期飼料給与量, 肉豚 1 頭当たり平均枝肉重量 (以下，枝肉重量)，上物率である。経済性は増体 $1 \mathrm{~kg}$ 当たり飼料費および枝肉 $1 \mathrm{~kg}$ 当たり生産費 （以下，枝肉生産費）である。

デー夕は調査期間毎に補正した後一元配置法で 処理し, 有意差は Duncanの多重検定で検定し た。

なお，調査期間中の豚枝肉卸売価格（円 $/ \mathrm{kg}$ ) は平成 6 年が 455 円，平成 7 年は 458 円，平成 8 年は 495 円，平成 9 年が 486 円であった5)。また,

表 2. 肉豚の発育性,

\begin{tabular}{|c|c|c|c|c|c|c|}
\hline \multirow{3}{*}{ 区 } & \multicolumn{6}{|c|}{ 発育性 } \\
\hline & \multirow{2}{*}{ 素豚体重 } & \multirow{2}{*}{ 出荷体重 } & \multirow{2}{*}{$\begin{array}{l}\text { 1日平均 } \\
\text { 増体重 }\end{array}$} & \multirow{2}{*}{ 飼料給与量 } & \multicolumn{2}{|r|}{ 発育期別飼料 } \\
\hline & & & & & 子豚育成期（A） & 子豚期（B） \\
\hline & (kg) & (kg) & (g) & （kg/頭） & (kg) & (kg) \\
\hline 1 & $8.0 \pm 2.1$ & $108.3 \pm 2.0$ & $595 \pm 41^{\mathrm{a}}$ & $312 \pm 16^{\mathrm{cd}}$ & $32 \pm 8^{b}$ & $132 \pm 21^{\mathrm{b}}$ \\
\hline 2 & $7.3 \pm 2.3$ & $107.3 \pm 1.6$ & $591 \pm 45^{\mathrm{a}}$ & $310 \pm 19^{d}$ & $32 \pm 8^{b}$ & $132 \pm 21^{\mathrm{b}}$ \\
\hline 3 & $6.9 \pm 1.6$ & $107.9 \pm 1.8$ & $564 \pm 31^{\mathrm{b}}$ & $318 \pm 14^{\mathrm{bcd}}$ & $32 \pm 10^{\mathrm{b}}$ & $131 \pm 27^{\mathrm{b}}$ \\
\hline 4 & $6.8 \pm 1.3$ & $108.4 \pm 2.2$ & $538 \pm 36^{c}$ & $323 \pm 18^{b c}$ & $36 \pm 13^{\mathrm{ab}}$ & $150 \pm 33^{b}$ \\
\hline 5 & $8.2 \pm 2.4$ & $108.1 \pm 2.1$ & $522 \pm 33^{\mathrm{cd}}$ & $325 \pm 23^{\mathrm{ab}}$ & $42 \pm 16^{\mathrm{a}}$ & $150 \pm 38^{\mathrm{b}}$ \\
\hline 6 & $8.8 \pm 2.1$ & $108.3 \pm 1.7$ & $502 \pm 32^{\mathrm{d}}$ & $337 \pm 18^{\mathrm{a}}$ & $32 \pm 6^{\mathrm{b}}$ & $173 \pm 25^{\mathrm{a}}$ \\
\hline
\end{tabular}

注 1）平均值士標準偏差。

2）行間の異符号間で有意差あり $(\mathrm{P}<0.05) 。$ 
肉豚用配合飼料価格（円 $/ 20 \mathrm{~kg}$ ）は平成 6 年が 708 円, 平成 7 年は 707 円, 平成 8 年は 839 円, 平 成 9 年が 842 円であった

\section{結果}

\section{（1） 発育性}

肉豚事故率別における肉豚の発育性を表 2 に示 した。肉豚仕向時の素豚体重は各区とも $6.8 \sim 8.8$ $\mathrm{kg}$ の範囲であり，また出荷時の体重む107.3〜 $108.4 \mathrm{~kg}$ の範囲で，各区における差はなかった。1 日平均増体重は 1 区が $595 \mathrm{~g}, 2$ 区は $591 \mathrm{~g}, 3$ 区は 564 g, 4 区は 538 g, 5 区は 522 g, 6 区は $502 \mathrm{~g}$ であ り，1 区および 2 区は 3 区，4 区，5区および 6 区 との間に，3区は 4 区，5区抢よび 6 区との間に， 4 区は 6 区との間に，それぞれ有意な差が認めら れた。

肉豚 1 頭当たりの飼料給与量は 1 区が $312 \mathrm{~kg}$, 2 区は $310 \mathrm{~kg}, 3$ 区は $318 \mathrm{~kg}, 4$ 区は $323 \mathrm{~kg}, 5$ 区は $325 \mathrm{~kg}$ ならびに 6 区は $337 \mathrm{~kg}$ であった。1 区は 5 区および 6 区との間に，2 区は 4 区，5 区および 6 区との間に，3 区および 4 区は 6 区との間に，そ れぞれ有意な差があった。次に，肉豚の発育期別 における飼料給与量では, 子豚育成期で 1 区が 32 kg, 2 区は $32 \mathrm{~kg}, 3$ 区は $32 \mathrm{~kg}, 4$ 区は $36 \mathrm{~kg}, 5$ 区は $42 \mathrm{~kg}, 6$ 区は $32 \mathrm{~kg}$ であり，1 区，2 区，3 区および 6 区は 5 区との間に有意な差があった。子豚期で
は 1 区が $132 \mathrm{~kg} ， 2$ 区は $132 \mathrm{~kg} ， 3$ 区は $131 \mathrm{~kg}, 4$ 区は $150 \mathrm{~kg}, 5$ 区は $150 \mathrm{~kg}, 6$ 区は $173 \mathrm{~kg}$ であり, 1 区，2 区，3 区，4 区および 5 区は 6 区との間に 有意差が認められた。肉豚期は 1 区が $148 \mathrm{~kg}, 2$ 区が $146 \mathrm{~kg}, 3$ 区が $155 \mathrm{~kg}$, 4 区が $137 \mathrm{~kg}, 5$ 区が $133 \mathrm{~kg}, 6$ 区が $132 \mathrm{~kg}$ であり, 3 区は 5 区および 6 区との間に，有意差が認められた。

飼料要求率は 1 区が $3.12 ， 2$ 区は $3.11 ， 3$ 区は 3.15，4 区は 3.18，5 区は 3.29 ならびに 6 区は 3.40 であった。1 区，2 区および 3 区は 5 区および 6 区 との間に，4区は 6 区の間に，それぞれ有意な差 があった。

\section{（2）枝肉成績}

肉豚事故率別における枝肉成績を表 2 に示し た。肉豚 1 頭当たり平均枝肉重量は各区とも 70.6 $\sim 71.3 \mathrm{~kg}$ の範囲で, 区間で差はなかった。枝肉の 上物率は 1 区が $51.3 \% ， 2$ 区は $52.8 \% ， 3$ 区は 49.9\%，4区は 48.7\%，5区は46.6\%，6区は $45.1 \%$ で，1 区は 6 区，2 区は 5 区および 6 区との 間に有意な差があった。

\section{（3）経済性}

肉豚事故率別における増体 $1 \mathrm{~kg}$ 当たり飼料費 および枝肉生産費を表 2 に示した。増体 $1 \mathrm{~kg}$ 当 たり飼料費は 1 区が 144 円， 2 区は 146 円， 3 区が 147 円，4区は 150 円，5 区は 153 円，6区は 164 円で，1 区は 5 区および 6 区と，2区，3 区および

枝肉成績および経済性

\begin{tabular}{|c|c|c|c|c|c|}
\hline \multirow{3}{*}{$\begin{array}{l}\text { 給与量 } \\
\text { 肉豚期 (C) }\end{array}$} & \multirow{3}{*}{ 飼料要求率 } & \multicolumn{2}{|c|}{ 枝肉成績 } & \multicolumn{2}{|c|}{ 経済性 } \\
\hline & & 甘内㲧旦 & 然安 & & \\
\hline & & 仅的王里 & 上㭷 $=$ & 飼料費 & 1X人 \\
\hline (kg) & & $(\mathrm{kg})$ & $(\%)$ & （円/kg） & (円/kg) \\
\hline $148 \pm 19^{\mathrm{ab}}$ & $3.12 \pm 0.17^{c}$ & $71.2 \pm 1.3$ & $51.3 \pm 7.3^{\mathrm{ab}}$ & $144 \pm 9^{c}$ & $393 \pm 31^{c}$ \\
\hline $146 \pm 25^{\mathrm{ab}}$ & $3.11 \pm 0.16^{\mathrm{c}}$ & $70.6 \pm 1.2$ & $52.8 \pm 6.9^{\mathrm{a}}$ & $146 \pm 12^{\mathrm{bc}}$ & $406 \pm 37^{c}$ \\
\hline $155 \pm 26^{\mathrm{a}}$ & $3.15 \pm 0.13^{c}$ & $71.0 \pm 1.3$ & $49.9 \pm 4.7^{\mathrm{ab}}$ & $147 \pm 14^{\mathrm{bc}}$ & $402 \pm 28^{c}$ \\
\hline $137 \pm 28^{\mathrm{ab}}$ & $3.18 \pm 0.21^{\mathrm{bc}}$ & $71.2 \pm 1.6$ & $48.7 \pm 6.6^{\mathrm{abc}}$ & $150 \pm 11^{\mathrm{bc}}$ & $407 \pm 33^{c}$ \\
\hline $133 \pm 29^{b}$ & $3.29 \pm 0.22^{\mathrm{ab}}$ & $70.9 \pm 1.4$ & $46.6 \pm 8.8^{\mathrm{bc}}$ & $153 \pm 12^{\mathrm{b}}$ & $448 \pm 31^{\mathrm{b}}$ \\
\hline $132 \pm 33^{b}$ & $3.40 \pm 0.22^{\mathrm{a}}$ & $71.3 \pm 1.2$ & $45.1 \pm 2.8^{c}$ & $164 \pm 13^{\mathrm{a}}$ & $471 \pm 43^{\mathrm{a}}$ \\
\hline
\end{tabular}


4 区は 6 区との間に，5区は 6 区との間に，それ ぞれ有意な差が認められた。

枝肉生産費は 1 区が 393 円, 2 区は 406 円，3 区 が 402 円，4区は 407 円，5区は 448 円，6 区は 471 円であった。1 区，2 区，3 区および 4 区は 5 区および 6 区との間に，5区は 6 区との間に，そ れぞれ有意な差が認められた。

\section{考察}

肉豚事故率が低い養豚一貫経営ほど, 肉豚の発 育および飼料効率で優れていることから, 肉豚に 関する肥育技術水準が高く, 肉豚の飼養環境およ び飼育管理は適正であると想定され，その結果増 体 $1 \mathrm{~kg}$ 当たり飼料費が低く，それに伴って枝肉 生産費も低くなったと思われる。

しかし, 中央畜産会の養豚経営改善指導資料7) による之, 肉豚仕向頭数に対する肉豚の事故率は 基準指標値および目標指標值でそれぞれ $2.0 \%$ 以 内および $1.5 \%$ 以内と設定している。また, 肉豚 事故率を規制する要因として，遺伝的要因として 強健性, 飼養管理として栄養条件, 飼養環境, 衛 生環境, 疾病予防管理および健康観察などをあげ ている。

従って, さらに肉豚の生産性向上を図るには, 肉豚の事故率を如何に低減するかが重要であり, 肉豚の飼養環境, 離乳時から $30 \mathrm{~kg}$ までの育成管 理, 衛生管理などに配慮して, 肉豚の事故率を低 減することが望まれる。

肉豚事故率が高い養豚一貫経営において, 飼料 要求率および増体 $1 \mathrm{~kg}$ 当たり飼料費が高いのは 事故豚に係わる飼料給与量および飼料費のほか に, 肉豚の発育の劣ったことが想定される。つま り, 肉豚の発育の遅れたことは肥育期間の延長に つながり，その結果肉豚 1 頭当たりの飼料給与量 が多くなったことによると推定される。

筆者ら ${ }^{8)}$ は肉豚 1 頭当たりの豚房面積が小さい 之肉豚は密飼いで飼育管理され，その結果肉豚の 事故率が高くかつ増体 $1 \mathrm{~kg}$ 当たり飼料費も高く なると指摘した。従って, 肉豚事故率の高い経営 では肉豚事故率を低減し, 肉豚の生産性向上に努 めるために, 肉豚はまず適正な面積で飼養管理す ることが望まれる。
庄内家畜保健衛生所において, 平成 11 年に管 内の肉豚死亡頭数 14,455 頭を体重別に調査した 結果, 体重が $45 \mathrm{~kg}$ までの子豚の死亡頭数割合が $78 \%$ を占め, その中で体重 16〜30 kg までが $50 \%$ と最む多く, 次に体重 $31 \sim 45 \mathrm{~kg}$ までが 17\%であったと報告した ${ }^{9)}$ 。本調査では, 肉豚に 対する発育期別の飼料給与量は肉豚事故率の高い 経営の子豚期における飼料給与量が肉豚事故率の 低い経営に比べ約 20〜 40 kg 多かった。

本調查における子豚期の飼料給与量から推定す る之, 肉豚の事故は庄内家畜保健衛生所の報告之 同様に子豚期で多く発生していると思われる。 従って，この期間における肉豚の事故防止のた め, 肉豚舎に移動後約 1 週間は温度なごの環境要 因に留意して肉豚を管理し，そして肉豚舎の環境 に早く慣れさせ，発育の停滞しないように管理す ることが大切と思われる。

枝肉成績において，枝肉重量で各区間の差がな かったことは各経営とも出荷技術として適正な体 重で肉豚を出荷していると思われるが, 肉豚事故 率の高い経営において枝肉の上物率が低かったこ とは肉豚の飼養環境を含めた飼育管理技術に差が あったと推察される。

筆者ら ${ }^{8)}$ は肉豚 1 頭当たりの豚房面積が小さい と肉豚は密飼いで飼育管理され, 肉豚の枝肉成績 では上物率が低いと報告した。このことは肉豚舎 を有効に利用するために肉豚を早期に出荷するこ とが多く，その結果脂肪付着の薄いことなどで格 落ちする枝肉が多くなったことによると指摘し た。従って, 肉豚事故率の高い経営では枝肉の上 物率向上を図るために, 肉豚は常に 1 豚房当たり の収容頭数は適正な面積を確保して飼養管理する ことが望まれる。

このように, 肉豚事故率の高い経営では肉豚に 対する飼育管理水準が低いことから, 肉豚の生産 性向上を図るには飼養環境および飼育管理の全面 的な改善が望まれる。そのため, 肉豚事故率の低 減を第一の目標として, 肉豚に対する飼養環境の 整備ならびに飼育管理の改善に努めることが要求 される。

つまり, 離乳子豚の発育向上を目的として子豚 育成豚舎を整備すること, 子豚および繁殖䧳豚に 
対するワクチネーションの検討, 肉豚は単位面積 当たりの収容頭数を適正にすること, 舎内の温 度, 湿度および換気に留意して肉豚の生育環境を 快適に保つことなど飼育管理の改善が望まれる。 さらに, 豚の疾病予防を目的として肉豚の飼育管 理作業に伴う器材などは豚舎毎に整備し, その豚 舎専用に使用することなどの管理作業の改善が望 まれる。

以上のことから, 枝肉生産費を低減し, 所得の 向上を図るために, 肥育技術の改善として肉豚事 故率の低減が要求され, 肉豚に対する飼養環境の 整備ならびに飼育管理技術の改善を図ることが必 要と思われる。

\section{文献}

1）中央畜産会 : 先進的畜産経営の動向・養豚
経営 (平成 10 年調查結果), 1999.

2）山形県畜産会: 経営診断からみた畜産経営 の現況 (養豚編) (平成 7 年度), 1996.

3）山形県畜産会: 経営診断からみた畜産経営 の現況（養豚編）(平成 8 年度), 1997.

4）山形県畜産会 : 経営診断からみた畜産経営 の現況（養豚編）(平成 9 年度), 1998.

5）農林水産省統計調査部：畜産物流通統計, 1998.

6）（社）日本飼料協会 : 飼料月報， $418,1998$.

7）中央畜産会 : 養豚経営改善指導指標（一貫 経営編), 1991.

8）今田哲雄 - 佐藤圭子 - 佐藤和枝 - 川村信雄 : 肉豚 1 頭当たり豚房面積が肉豚の肥育成 績ならびに経済性に及ぼす影響, 日豚会 誌, 35, 37-39, 1998.

9）山形県畜産会: 山形県畜産会指導情報（肉 豚事故率の低減について)，7-14, 2000. 